\title{
Carbon Syntactic Foam Mechanical Properties Testing
}

Federal Manufacturing \& Technologies

G. W. McEachen

KCP-613-6043

Published January 1998

DISTRIBUTON OF THIS DOCUMENT IS UNUMMTED

\section{Topical Report}

Approved for public release; distribution is unlimited.

\section{MASTER}

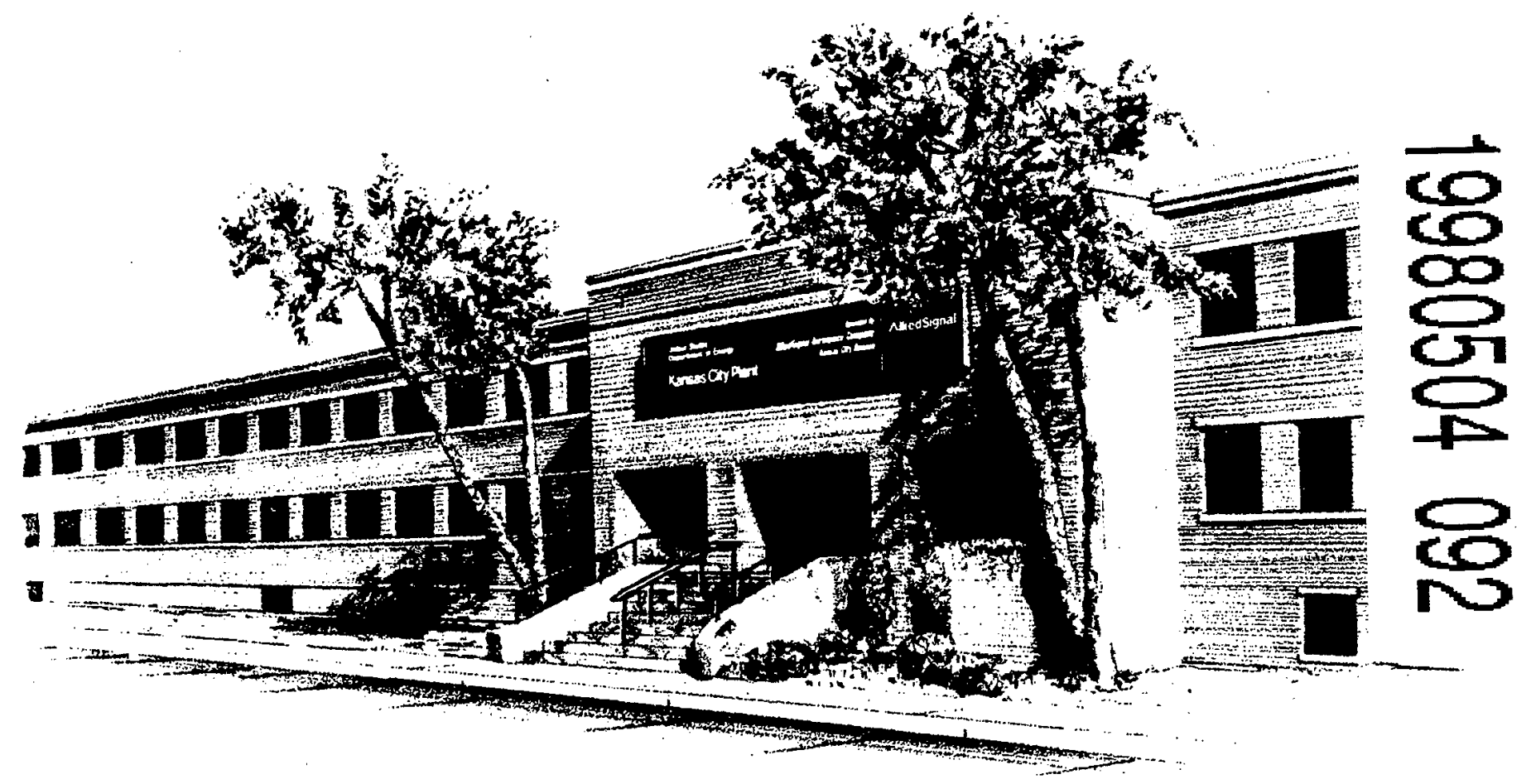

Prepared Under Contract Number DE-ACO4-76-DP00613 for the

United States Department of Energy

AlliedSignal 


\section{DISCLAIMER}

This report was prepared as an account of work sponsored by an agency of the United States Government. Neither the United States Government nor any agency thereof, nor any of their employees, makes any warranty, express or implied, or assumes any legal liability or responsibility for the accuracy, completeness, or usefulness of any information, apparatus, product, or process disclosed, or represents that its use would not infringe privately owned rights. Reference herein to any specific commercial product, process, or service by trade names, trademark, manufacturer, or otherwise, does not necessarily constitute or imply its endorsement, recommendation, or favoring by the United States Government or any agency thereof. The views and opinions of authors expressed herein do not necessarily state or reflect those of the United States Government or any agency thereof.

All data prepared, analyzed and presented has been developed in a specific context of work and was prepared for internal evaluation and use pursuant to that work authorized under the referenced contract. Reference herein to any specific commercial product, process or service by trade name, trademark, manufacturer, or otherwise, does not necessarily constitute or imply its endorsement, recommendation, or favoring by the United States Government, any agency thereof or AlliedSignal Inc.

Printed in the United States of America.

This report has been reproduced from the best available copy.

Available to DOE and DOE contractors from the Office of Scientific and Technical Information, P. O. Box 62, Oak Ridge, Tennessee 37831; prices available from (615) 576-8401, FTS 626-8401.

Available to the public from the National Technical Information Service, U. S. Department of Commerce, 5285 Port Royal Rd., Springfield, Virginia 22161.

A prime contractor with the United States Department of Energy under Contract Number DE-ACO4-76-DP00613.
AlliedSignal Inc. Federal Manufacturing \& Technologies P. O. Box 419159 Kansas City, Missouri 64141-6159 
KCP-613-6043

Distribution Category UC-706

Approved for public release; distribution is unlimited.

\section{CARBON SYNTACTIC FOAM}

MECHANICAL PROPERTIES TESTING

\section{G. W. McEachen}

Published January 1998

Topical Report

G. W. McEachen, Project Leader 


\section{Contents}

$\begin{array}{lll}\text { Section } & \text { Page }\end{array}$

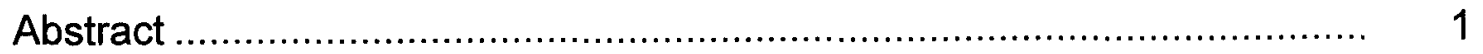

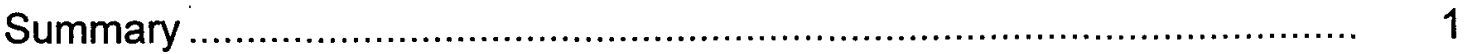

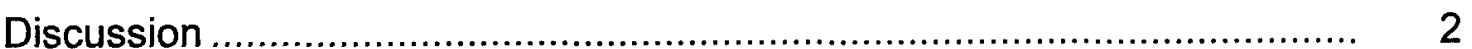

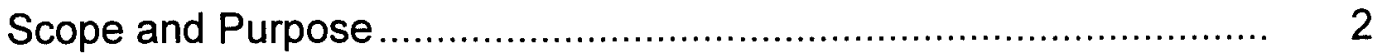

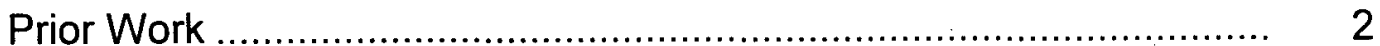

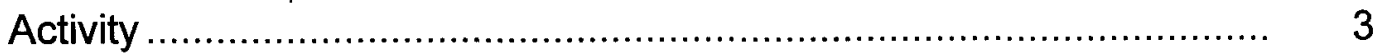

Mechanical Properties Testing ............................................. 5

Compression Testing.............................................................. 5

Tensile Testing ................................................................... 5

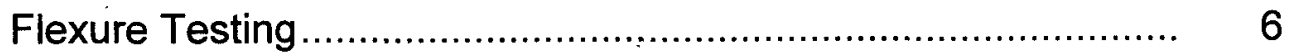

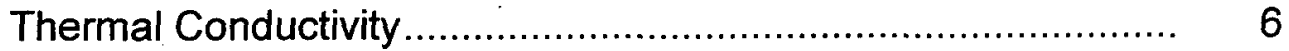

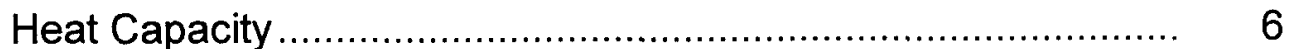

Moisture Absorption............................................................. 6

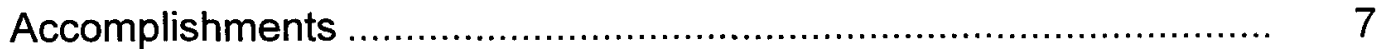

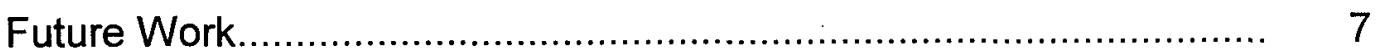

Appendix. Supporting Data in Illustrations............................................ 8 


\section{Illustrations}

Figure

Page

1 Cure Cycles Used for the Carbon Syntactic Foam During the Process Development Effort in 1996 and 1997 ......................... 8

2 Compression Strength Versus Density .............................................. 9

3 Compression Strength of Carbon Syntactic Foam in a Time Sequence

4 Compression Strength and Modulus of Elasticity, Tested at Room Temperature

5 Compression Strength and Modulus of Elasticity Versus Density, Tested at $200^{\circ} \mathrm{F}$

6 Compression Strength and Modulus of Elasticity Versus

Density, Tested at $400^{\circ} \mathrm{F}$

7 Tensile Strength Versus Density, Tested at Room Temperature

8 Flexure Strength and Modulus of Elasticity Versus Density, Tested at Room Temperature

9 Flexure Strength and Modulus of Elasticity Versus Density, Tested at $200^{\circ} \mathrm{F}$......

10 Flexure Strength and Modulus of Elasticity Versus Density, Tested at $400^{\circ} \mathrm{F}$....

11 Thermal Conductivity of Carbon Syntactic Foam, Tested at Room Temperature

12 Thermal Conductivity of Carbon Syntactic Foam Versus Density, Tested at $200^{\circ} \mathrm{F}$

13 Thermal Conductivity of Carbon Syntactic Foam Versus Density, Tested at $400^{\circ} \mathrm{F}$......

14 Moisture Absorption in Carbon Syntactic Foam 


\begin{abstract}
The mechanical properties of the carbon/APO-BMI syntactic foam were improved through refinements in the cure cycle.
\end{abstract}

\title{
Summary
}

This project was started early in the redevelopment of the carbon syntactic foam. The new mixture of carbon microballoons with the APO-BMI resin had not been fully characterized, but that was the actual purpose of this effort. During the forming of the billets for these tests, a problem began to surface; but full understanding of the problem did not evolve until samples were cured and tests were conducted. Material compressive strengths varied between 200 and 990 psi where anything below 700 was rejected. The cure cycle was adjusted in an iterative manner in an attempt to maximize the material strength. The result of this effort was that the material strength was almost doubled and was achieving strengths of 1500 psi toward the end of the parts produced.

As a consequence, some of the strength tests actually run and reported in the text of this report may not reflect data that would be obtained today. The material strength was continuously being improved over the entire year. A complete series of compression test data is reported, but subsequent tensile and flexural strength tests were not repeated. At a time when it is considered that there are no further changes to be incorporated, a repeat of these tests would be warranted.

Some development remains to be done on the carbon microballoon material. Improved carbon material is now available and its effect of the material strength should be evaluated. 


\section{Discussion}

\section{Scope and Purpose}

The scope of this report was to obtain data for the physical properties of APO-BMI resin-based carbon syntactic foam. All properties were to be obtained at densities ranging from 0.28 to $0.32 \mathrm{~g} / \mathrm{cm}^{3}$ with a data point at $0.30 \mathrm{~g} / \mathrm{cm}^{3}$ design point. The test properties desired were:

1. Tensile strength at $70^{\circ} \mathrm{F}$ and at $400^{\circ} \mathrm{F}$.

2. Compressive strength at $70^{\circ} \mathrm{F}$ and at $400^{\circ} \mathrm{F}$.

3. Young's Modulus for the tensile and compressive strength tests.

4. Thermal conductivity and heat capacity in the range of -40 to $+400^{\circ} \mathrm{F}$.

5. Moisture absorption characteristics, grams water per gram foam in the range of -60 to $+50^{\circ} \mathrm{F}$ dew point.

\section{Prior Work}

To produce the test specimens needed for the list of tests, a mold was selected that produced a block of foam $8 \times 8 \times 1.5$ inches. The mold used for the desired billet size was designed and used in the early development of the carbon foams in the 1970s. All faces can be dissembled into 5 flat bars and the lid (ram). The lid acts as a side for one of the smaller surfaces and performs the action of a ram which subsequently compresses the foam in the direction of the greater width of the billet.

The carbon syntactic material is a mixture of carbon microballoons, thermosetting resin, and Thornel Mat Carbon Fiber. The materials were all to the same specification, except the resin was to be APO-BMI that is a proposed MDA-free replacement for the Kerimid 601 resin.

The amount of mixture of material going into the mold was varied to achieve the density as close as possible to $0.28,0.30$, and $0.32 \mathrm{~g} / \mathrm{cm}^{3}$.

The cure cycle for the process that was used at this time was identical to a previously used cure cycle for the glass microballoons with the resin APO-BMI. This was essentially to heat the mold in an oven at $320^{\circ} \mathrm{F}$ until the mold reached $270^{\circ} \mathrm{F}$. At that temperature, the mold is removed from the oven and the lid is pressed to a fully closed position. The mold was then returned to the oven and the temperature was set to $450^{\circ} \mathrm{F}$ and held for 4 hours. 


\section{Activity}

The various test samples were cut from the $8 \times 8 \times 1.5$ inch billets. As the test specimens were cut, weights and measurements were taken. It was noted that the density varies within the billet. This was not new information for the material specialists, in that the carbon microballoon resin mixture does not compress uniformly through the height of the mold. The result was that the various test specimens could not be controlled to a density value but needed to be measured and calculated for each test specimen. Therefore, the data will reflect a wider range of density results, and, while the density of $0.30 \mathrm{~g} / \mathrm{cm}^{3}$ was a target, it was not a controllable variable. It was also found that the density of all the test specimen parts from the $8 \times 8 \times 1.5$ billet had lower density than the whole billet itself.

While removing the billets from the mold for the higher density samples, a condition was observed that became more prevalent when production of regular parts in the aft support billets began. The condition was that the material appeared to be more "flaky" or "crumbly" on some billets than on others. One billet produced was so bad it was discarded. The condition really became unacceptable during testing of compression specimens from the rings of the aft support billets, and the compression strength dropped to as low as $280 \mathrm{psi}$, which is excessively low. The material was studied with the differential scanning calorimeter (DSC). This test measures the amount of energy that is absorbed or released by the material while the material is heated. Energy is released by an exothermic chemical reaction (epoxy curing) or absorbed during endothermic reactions (a phase change from solid to a liquid). From this study, the cure cycle for the carbon foam was modified and the modifications were evaluated. The resultant cure cycle attempts to slow down the heating of the outside of the mold so the difference between the inside and outside is reduced. It was also found to be important to have the syntactic mixture temperature rise from about $185^{\circ} \mathrm{F}$ to $270^{\circ} \mathrm{F}$ as slowly as reasonably possible. Also, after the mold lid is pressed into place, the following temperature rise needs to be gradual. When the mold temperatures are monitored following pressing the lid into place, the temperature was found to have falien to $225^{\circ} \mathrm{F}$ or less, and therefore it was important to allow time in the oven for the mold to reestablish the $270^{\circ} \mathrm{F}$ temperature before beginning the subsequent temperature rise. The temperature of $270^{\circ} \mathrm{F}$ is the temperature where the mixture is considered in a liquid phase after passing through the point of greatest endothermic condition. This temperature is also the ideal temperature to press the lid into place.

Based on these concerns, the thermocouple was located in the syntactic mixture in addition to being mounted on the mold, so that the actual mixture temperature could be better monitored during this heat up. The resultant process requires the mold to be heated as follows: 
- Set the oven at $200^{\circ} \mathrm{F}$ and hold until the powder reaches $130^{\circ} \mathrm{F}$.

- Reset the oven at $320^{\circ} \mathrm{F}$ and hold until the powder reaches $270^{\circ} \mathrm{F}$.

- Remove the mold from the oven and press the lid into place.

- Return the mold to the oven.

- Reset the oven to $275^{\circ} \mathrm{F}$ and hold for 1 hour.

- Reset the oven to $350^{\circ} \mathrm{F}$ and hold for $1 / 2$ hour.

- Reset the oven to $450^{\circ} \mathrm{F}$ and hold for $4 \frac{1}{2}$ hours.

A graphical representation of the process sequence is presented in Figure 1. (All figures are in the Appendix.) The results of these processing changes are in Figure 2 and titled "Compression Strengths as Related to the Process."

The improvement in strength for the material in the density range of about $0.31 \mathrm{~g} / \mathrm{cm}^{3}$ was significant. The data in Figure 2 represents all tests over the period of November 1996 through August 1997. To get a better appreciation of the improvement as time passed, the data was sorted accordingly. This information is provided in Figure 3 . Over this period of time numerous setbacks were encountered, as represented by the low data points, and subsequent adjustments to the process followed. At the end, some significant improvement in the strength results was observed.

Another problem that occurred during the aft support fabrication was the plan to incorporate a "new" carbon material. The carbonized microballoons are produced from phenolic microballoons previously produced by Union Carbide. Since the last production activity, Union Carbide transferred their license to Asian Pacific in Malaysia. As this was a very different source for the phenolic material, the material needed to be tested and evaluated. The first billets were tested as soon as possible and had compression strength results below $500 \mathrm{psi}$. A controlled experiment was conducted in our materials laboratory where several blocks of foam were cured using the "new" material with the resin only, the old material and the resin only, and a blend using the new material blended in the production department with the resin and a carbon fiber material. These billets were compression strength tested and had the following results:
Old carbon plus resin
170 psi
New carbon plus resin
$739 \mathrm{psi}$
New carbon, resin, and material
530 psi

The results were considered conclusive. There was something about the "new" material that resulted in low strength. The remainder of the aft support development utilized carbon material that had been in storage since production operations had ceased. Further evaluation of the "new" material brought concern that the ash content might be a source of the problem. The ash content requirement is $4 \%$ maximum, and the results of the first lot of material was $3.66 \%$. The supplier of the carbonization process is Fiber Materials Inc., FMI. FMI is located in Biddeford, Maine, and they immediately started to develop and incorporate a modification to the carbonization 
process. The process involves an inert gas flow through the carbon powder. That gas flow was changed to filter through the actual powder. This redirecting of the gas flow should do a better job of extracting the elements that are in gas form during the high temperature carbonization cycle. The resultant ash content was reported to be less than $1 \%$. The modified material was received at Federal Manufacturing \& Technologies on September 29, 1997, and has had no further evaluation as of the date of this writing:

\section{Mechanical Properties Testing}

It must be highlighted that the mechanical testing of this project preceded the compression testing required for the aft support hardware project. The data results for the compression testing on the hardware was discussed in a previous paragraph (and reported in Figures 2 and 3 ) because of the significance of understanding that the process evolved. The changes were necessitated by very low compression strength results. The fact that the process changed and improved the strength of the material does affect the conclusions that can be taken from this study on strength properties.

\section{Compression Testing}

The compression tests samples for this project were machined from the $8 \times 8 \times 1.5$ inch billet and tested. The test objective was to establish a comparison for the strength at room temperature, $200^{\circ} \mathrm{F}$, and $400^{\circ} \mathrm{F}$. The results of the temperature comparisons are plotted in Figures 4,5 , and 6 . The results for the three temperatures are nearly the same for a given density condition.

The compression strength results on this series of tests was lower than data reported in 1977. That data does not relate density, and it is possible that the density was somewhat higher than $0.30 \mathrm{~g} / \mathrm{cm}^{3}$. At $0.32 \mathrm{~g} / \mathrm{cm}^{3}$ this test series compares closely to the previous data.

\section{Tensile Testing}

Tensile tests were conducted in accordance with the guidelines specified in ASTM D1623. Since the billet material was insufficient to machine a full-sized ASTM sample, a proportionally smaller sample was used for all tensile tests.

Testing was conducted in two different phases: one for tensile strength and the other for modulus of elasticity measurements. These tests were conducted separately due to the notch sensitivity of the material when using the extensometer.

All testing was conducted at room temperature because of the wide variability in the material and the difficulty in the use of the ASTM fixturing. The final results from the tensile tests are provided in Figure 7. 
The tensile strength varied in this test series between 125 to $205 \mathrm{psi}$ as compared to 180 to 320 psi in 1977 . The test itself is very delicate and the data reflects the variability due to that sensitivity.

\section{Flexure Testing}

The test results for the flexure testing are provided in Figures 8, 9, and 10.

The flexure strength test results for this series of tests were less than previously reported in 1977. The reported flexure strength was $555 \mathrm{psi}$ at room temperature. These current test results were $210 \mathrm{psi}$ at room temperature, $260 \mathrm{psi}$ when tested at $200^{\circ} \mathrm{F}$, and $300 \mathrm{psi}$ when tested at $400^{\circ} \mathrm{F}$.

\section{Thermal Conductivity}

The test results for the thermal conductivity testing are provided in Figures 11, 12, and 13. The reported thermal conductivity was 0.269 watts/meter ${ }^{\circ} \mathrm{C}$ in 1977 and also at about 0.21 watts $/$ meter ${ }^{\circ} \mathrm{C}$ at $0.30 \mathrm{~g} / \mathrm{cm}^{3}$ density. The results from this study were 0.22 watts $/$ meter ${ }^{\circ} \mathrm{C}$ at room temperature, 0.25 watts $/$ meter ${ }^{\circ} \mathrm{C}$ at $200^{\circ} \mathrm{F}$, and 0.31 watts $/$ meter ${ }^{\circ} \mathrm{C}$ at $400^{\circ} \mathrm{F}$.

\section{Heat Capacity}

The first approach to determining the heat capacity was by combining the individual heat capacities of carbon and APO-BMI resin, in the mix ratios. For this, carbon is estimated to be $0.17 \mathrm{cal} / \mathrm{g}{ }^{\circ} \mathrm{C}$ and APO-BMl and is figured at $0.45 \mathrm{cal} / \mathrm{g}{ }^{\circ} \mathrm{C}$. The carbon's contribution would be $65 \%$ of the total times the 0.17 to equal $0.15 \mathrm{cal} / \mathrm{g}{ }^{\circ} \mathrm{C}$. Similarly, the resin's contribution of $40 \%$ of the total times the 0.45 to equal $0.171 \mathrm{cal} / \mathrm{g}{ }^{\circ} \mathrm{C}$. The total heat capacity of the syntactic foam blend would be the sum of the two, or $0.276 \mathrm{cal} / \mathrm{g}{ }^{\circ} \mathrm{C}$. The approximations with these were that the resin is based on the value for an epoxy resin and graphite is used for the carbon value. To confirm these approximations, a DSC test was run on a sample of the cured foam. That result was $0.24 \mathrm{cal} / \mathrm{g}{ }^{\circ} \mathrm{C}$, which turned out to be reasonably close to the previous rough estimate.

\section{Moisture Absorption}

Initially a program was developed to measure the moisture absorption on samples 0.700 inch diameter and 3.5 inches long at moisture conditions of $32,24.4,4.13,0.516$, and $\sim 0.0187 \%$ relative humidities. The results from the middle three conditions were well documented. The saturation condition for $24.4 \% \mathrm{RH}$ was about $0.003 \mathrm{~g}$ water $/ \mathrm{g}$ foam, at $4.13 \% \mathrm{RH}$ the result was about $0.004 \%$, and at $0.52 \% \mathrm{RH}$ the moisture pickup was essentially zero. These tests results were initially questioned. Bulk pieces of carbon foam remaining from the ring removed during cutting the compression samples were then used so as to have a larger surface area for evaluation. Six (6) large 
(surface area) samples from two billets were used. The material was dried and weighted in a the glove box having a moisture content of less than $0.0187 \%$ relative humidity. The parts were then transferred to a chamber having $27 \%$ relative humidity, and weight readings were taken about every 5 minutes for the first hour and then every 10 minutes for the next hour, 20 minutes for the third hour, followed by 1 hour for the conclusion of the first day. The readings were taken most days through the following 10 days. The saturation results were about $0.007 \mathrm{~g}$ water $/ \mathrm{g}$ foam. The results are presented in Figure 14.

The moisture absorption leveled out at an average result of 0.690 gram $\mathrm{H}_{2} \mathrm{O}$ per gram foam. This compared well to documents released by the UK which reported a moisture absorption for $30 \% \mathrm{RH}$ to be about 0.700 gram $\mathrm{H}_{2} \mathrm{O}$ per gram foam.

\section{Accomplishments}

This project was started early in the redevelopment of the carbon syntactic foam. The new mixture of carbon microballoons with the APO-BMI resin had not been fully characterized, but that was the actual purpose of this effort. During the forming of the billets for these tests, a problem began to surface; but full understanding of the problem did not evolve until samples were cured and tests were conducted. Material compressive strengths varied between 200 and 990 psi where anything below 700 was rejected. The cure cycle was adjusted in an iterative manner in an attempt to maximize the material strength. The result of this effort was that the material strength was almost doubled and was achieving strengths of 1500 psi toward the end of the parts produced.

As a consequence, some of the strength tests actually run and reported in the text of this report may not reflect data that would be obtained currently. The material strength was continuously being improved over the entire year. A complete series of compression test data is reported, but subsequent tensile and flexural strength tests were not repeated. At a time when it is considered that there are no further changes to be incorporated, a repeat of these tests would be warranted.

\section{Future Work}

Some development remains to be done on the carbon microballoon material. Improved carbon material is now available and its effect of the material strength should be evaluated. 


\section{Appendix}

\section{Supporting Data in Illustrations}
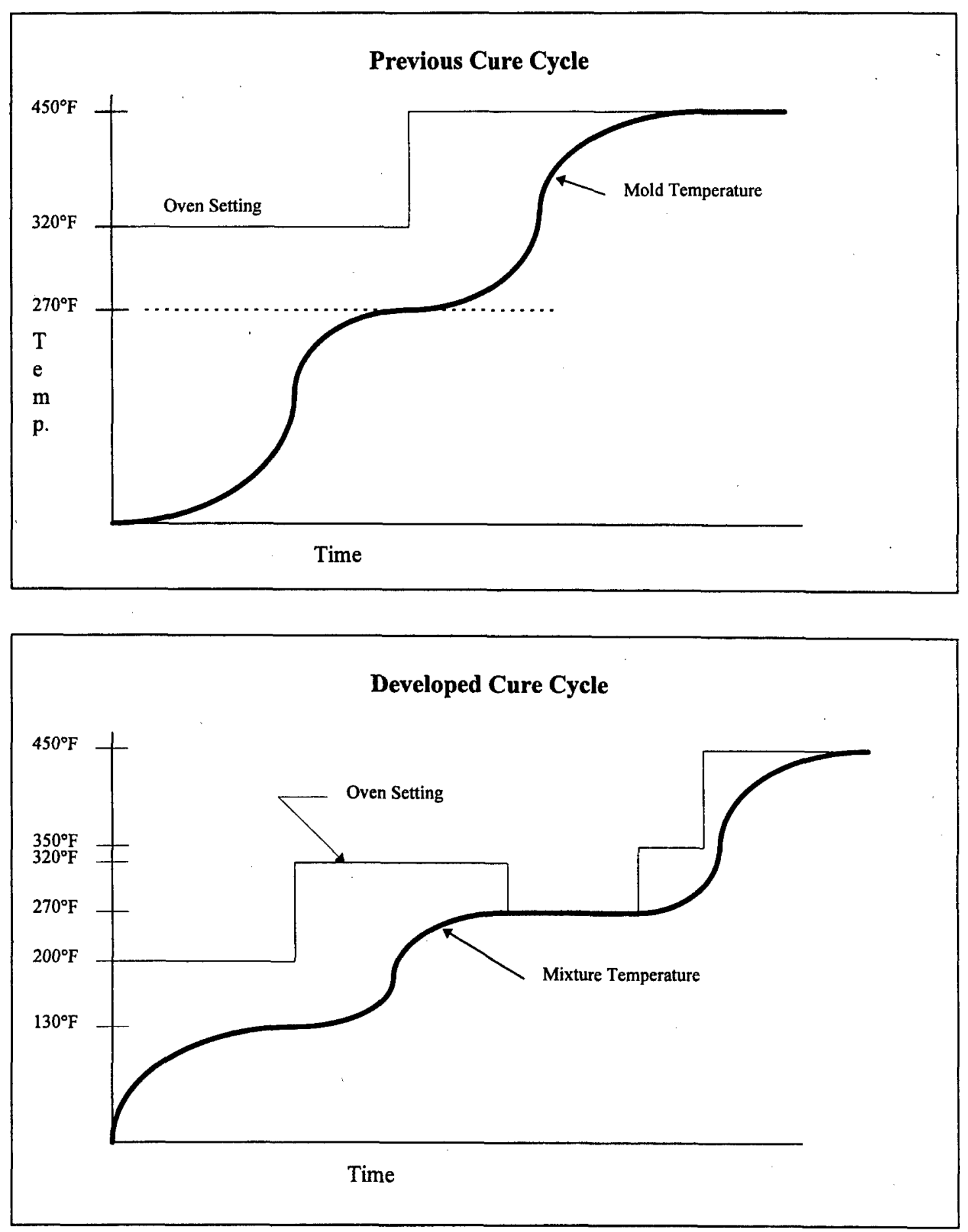

Figure 1. Cure Cycles Used for the Carbon Syntactic Foam During the Process Development Effort in 1996 and 1997 


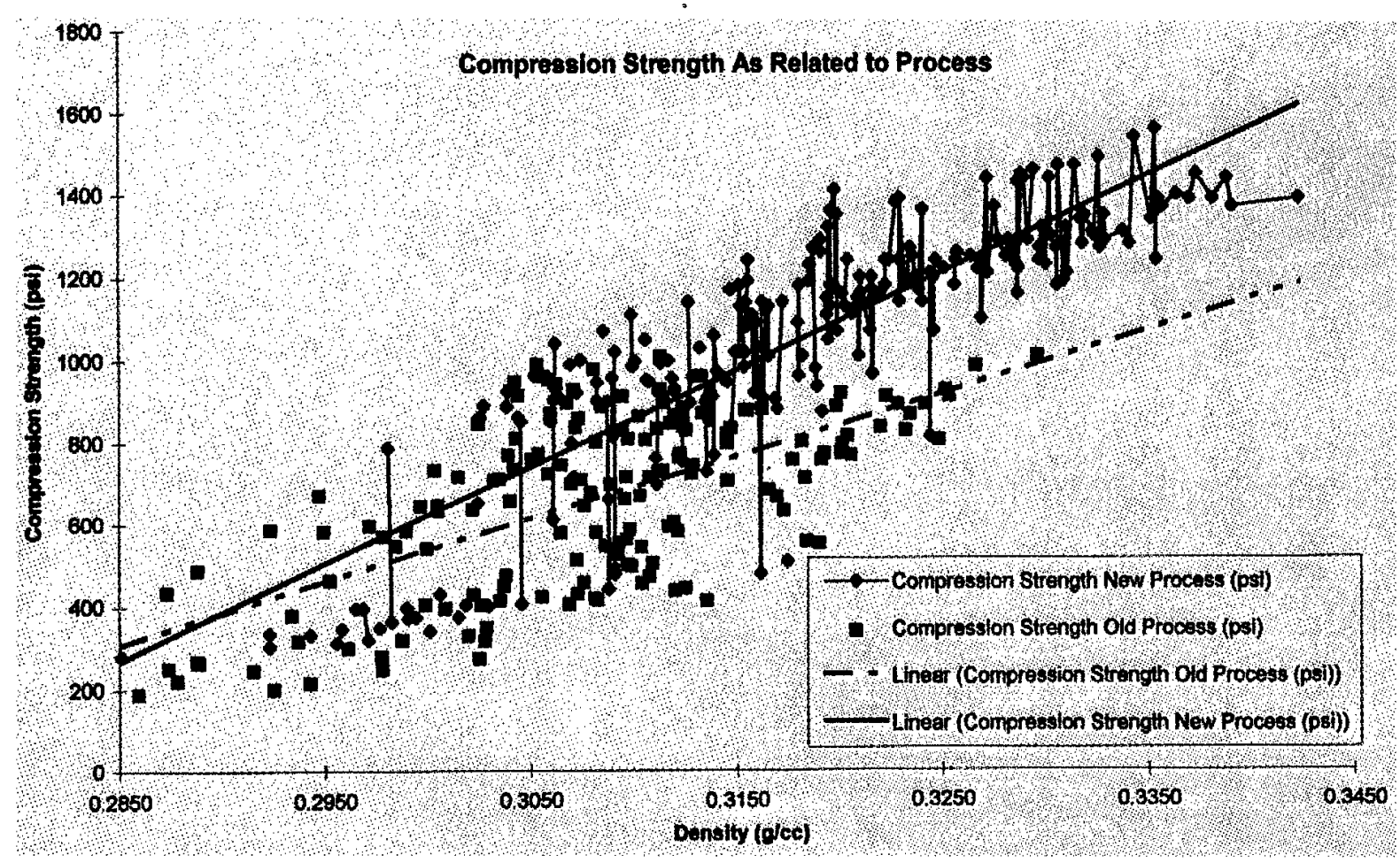

Figure 2. Compression Strength Versus Density

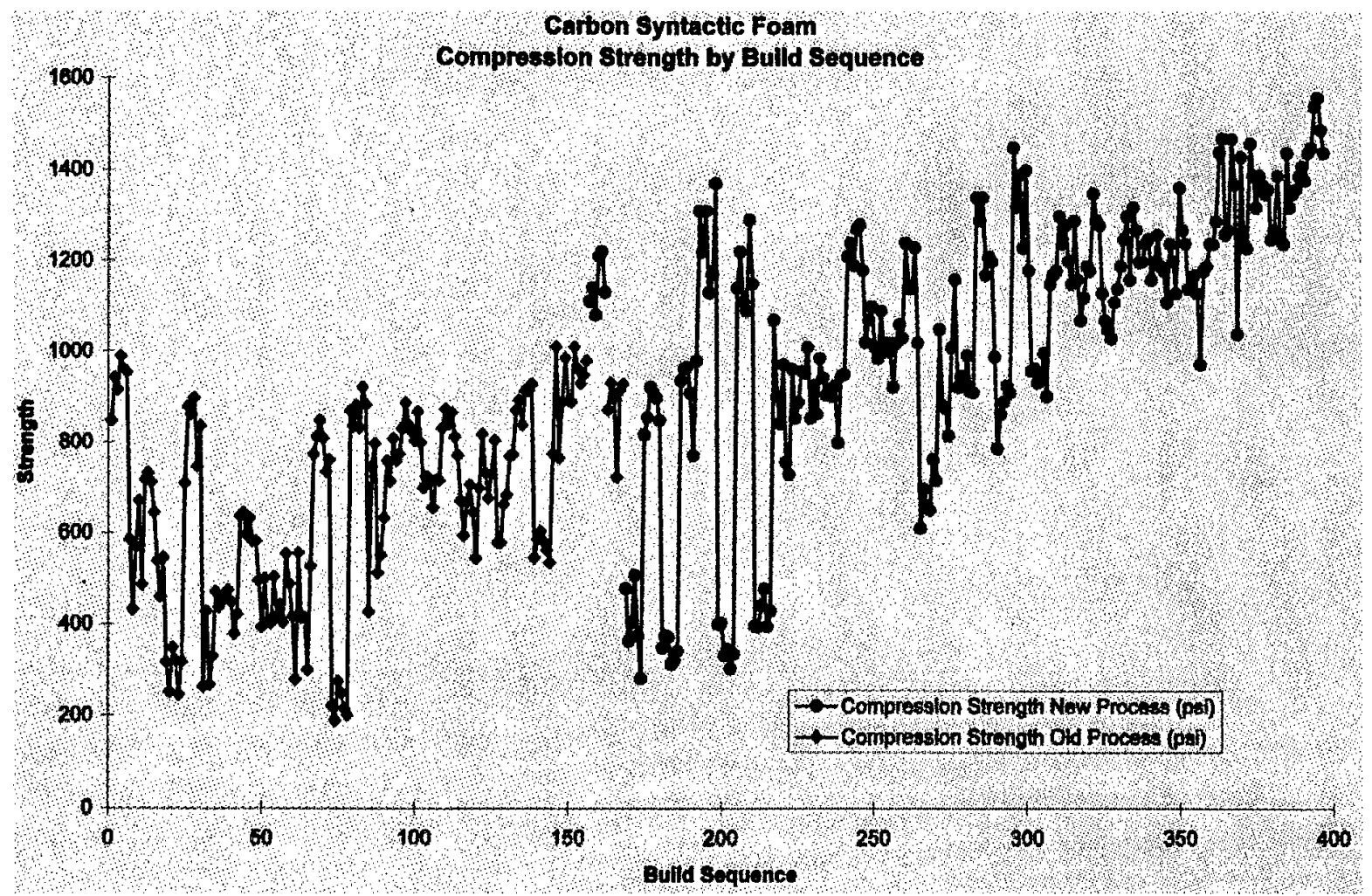

Figure 3. Compression Strength of Carbon Syntactic Foam in a Time Sequence 


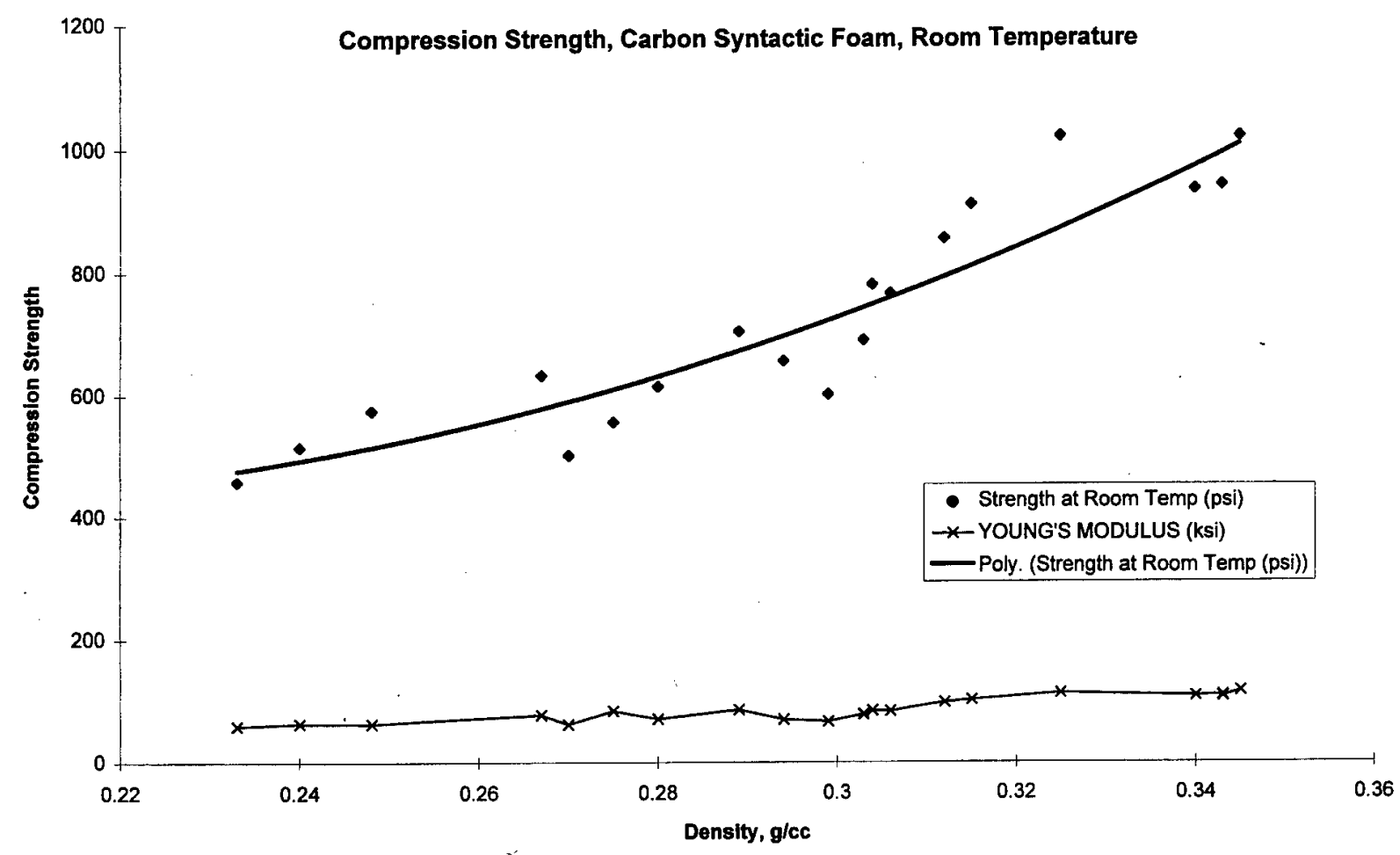

Figure 4. Compression Strength and Modulus of Elasticity, Tested at Room Temperature

Compression Strength, Carbon Syntactic Foam, $200^{\circ} \mathrm{F}$

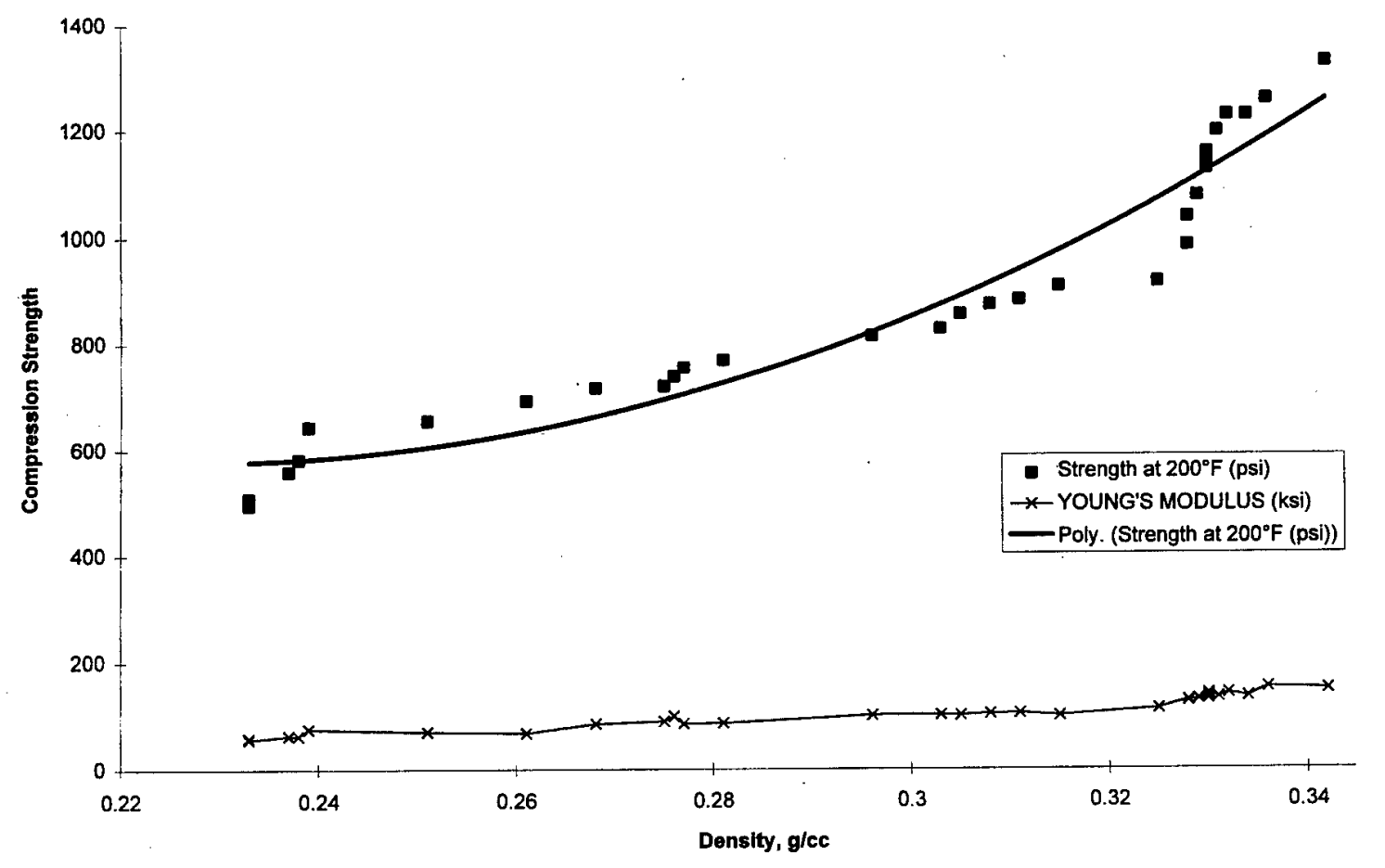

Figure 5. Compression Strength and Modulus of Elasticity Versus Density, Tested at $200^{\circ} \mathrm{F}$ 


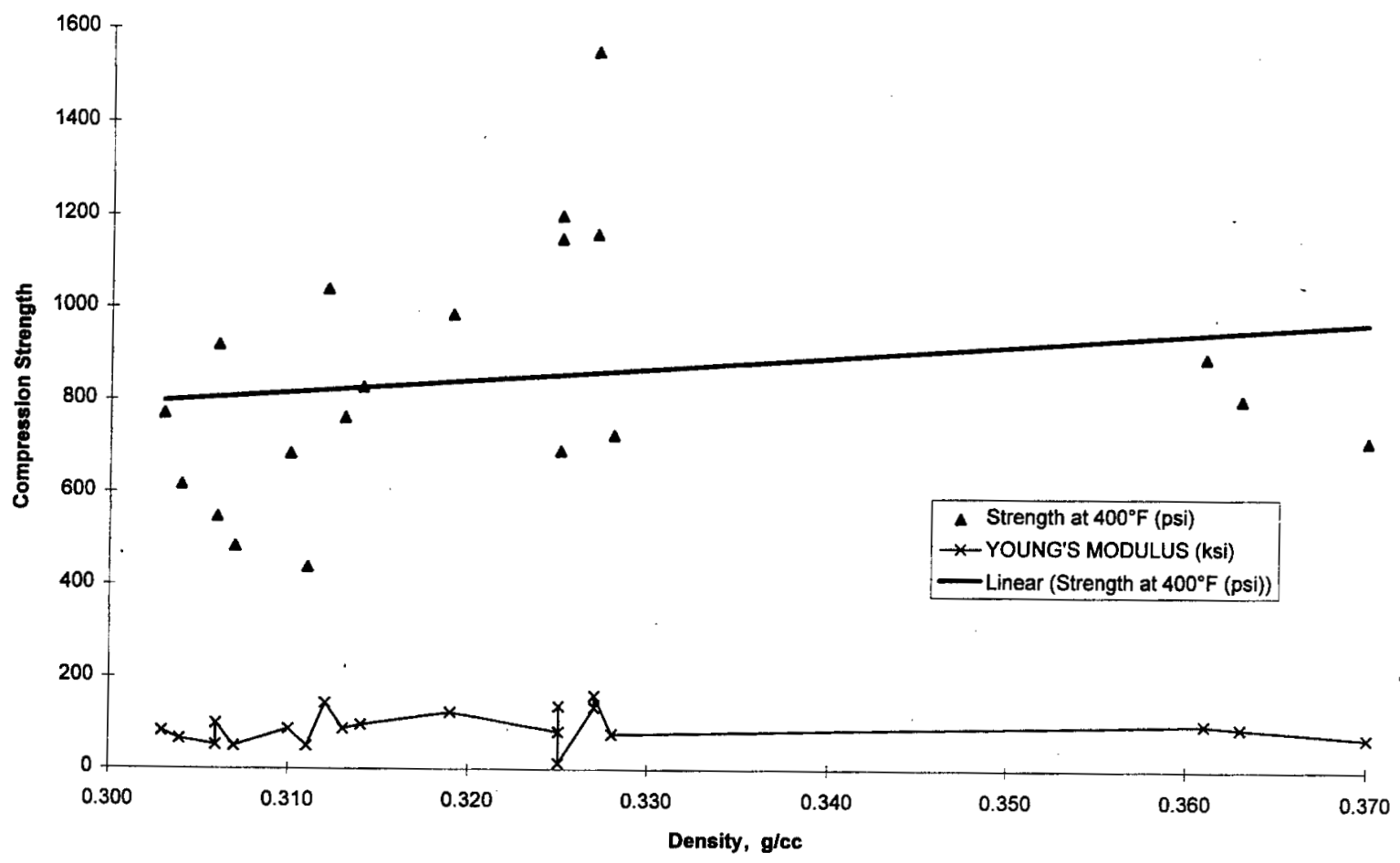

Figure 6. Compression Strength and Modulus of Elasticity Versus Density, Tested at $400^{\circ} \mathrm{F}$

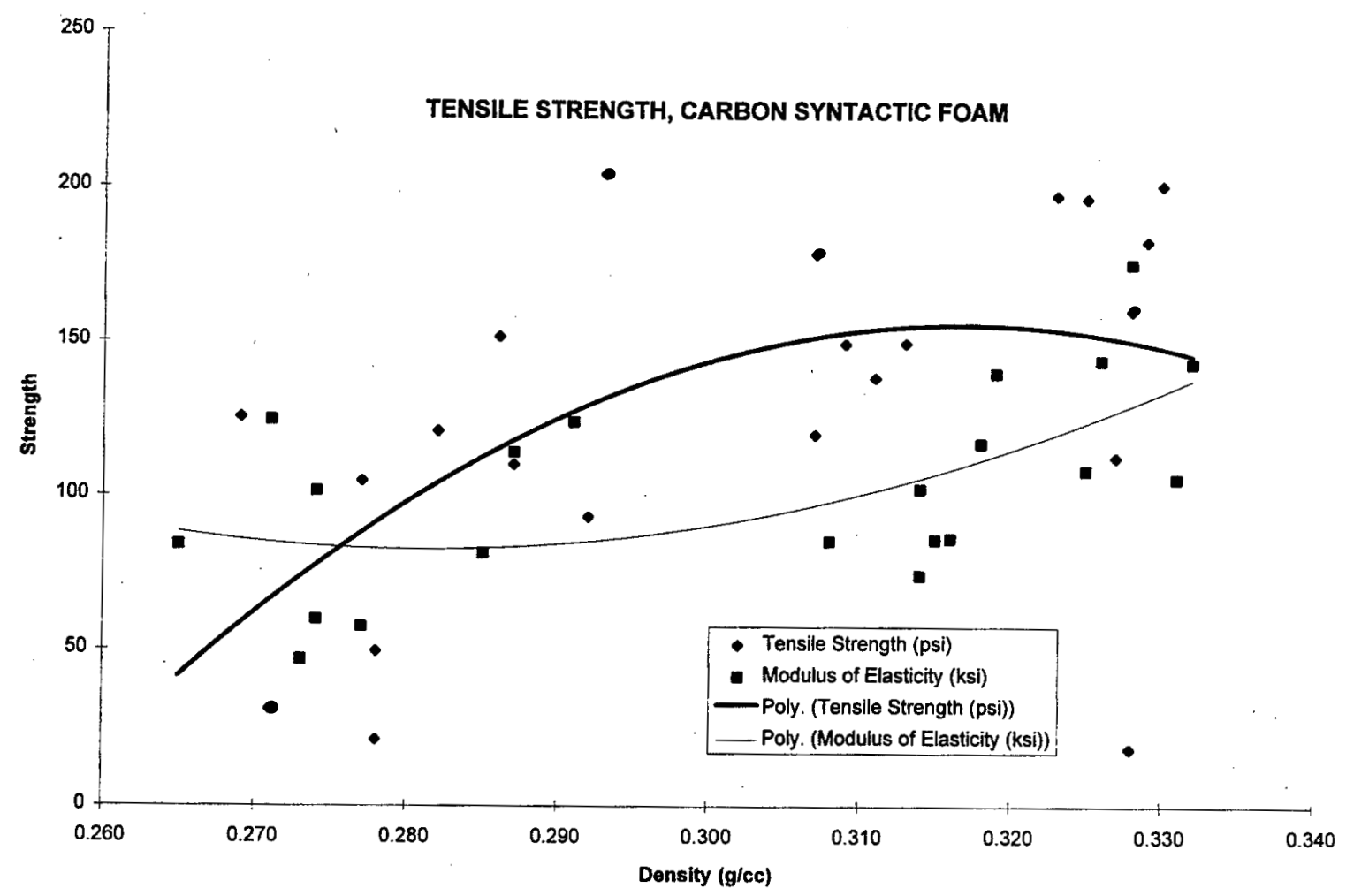

Figure 7. Tensile Strength Versus Density, Tested at Room Temperature 


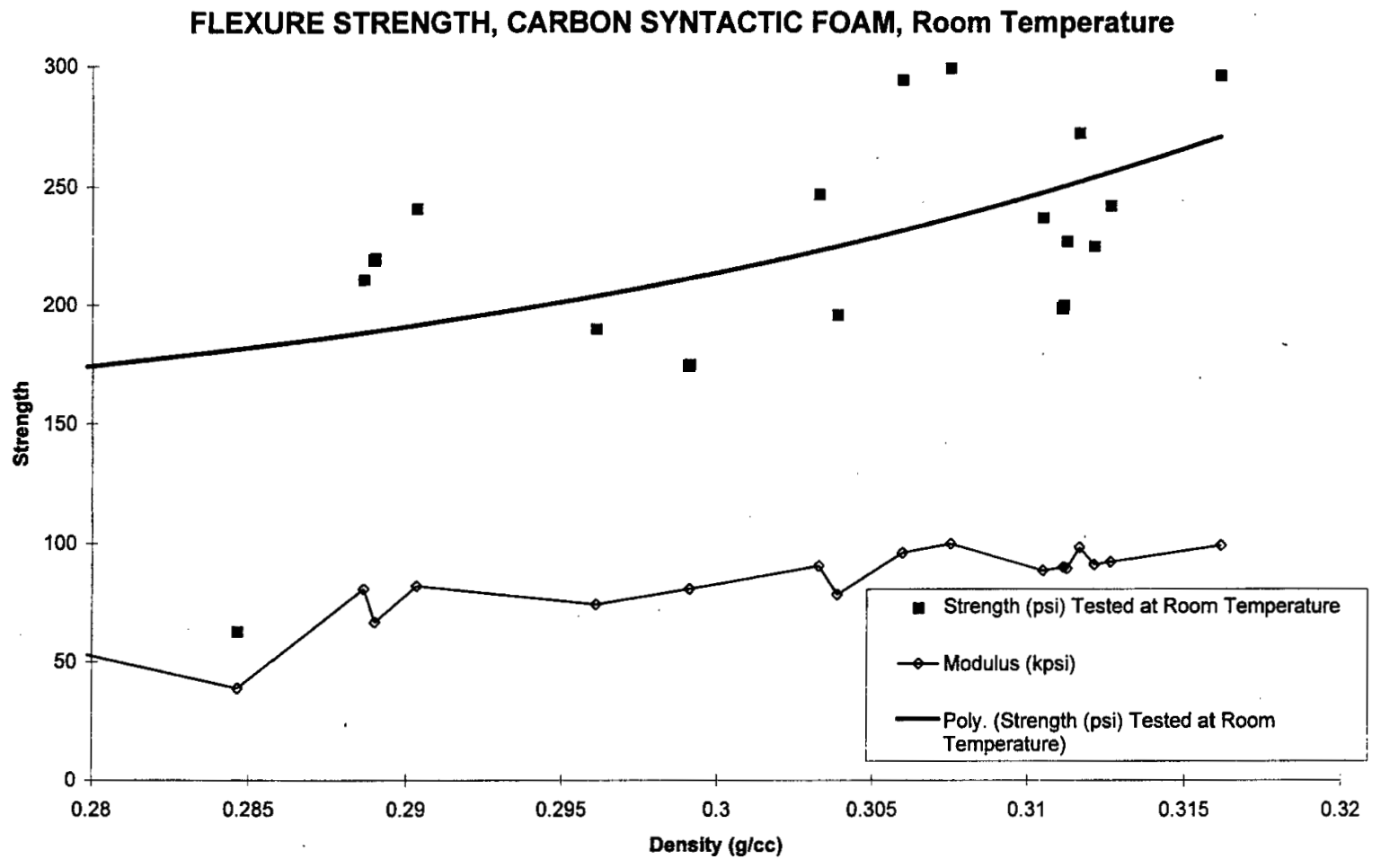

Figure 8. Flexure Strength and Modulus of Elasticity Versus Density, Tested at Room Temperature

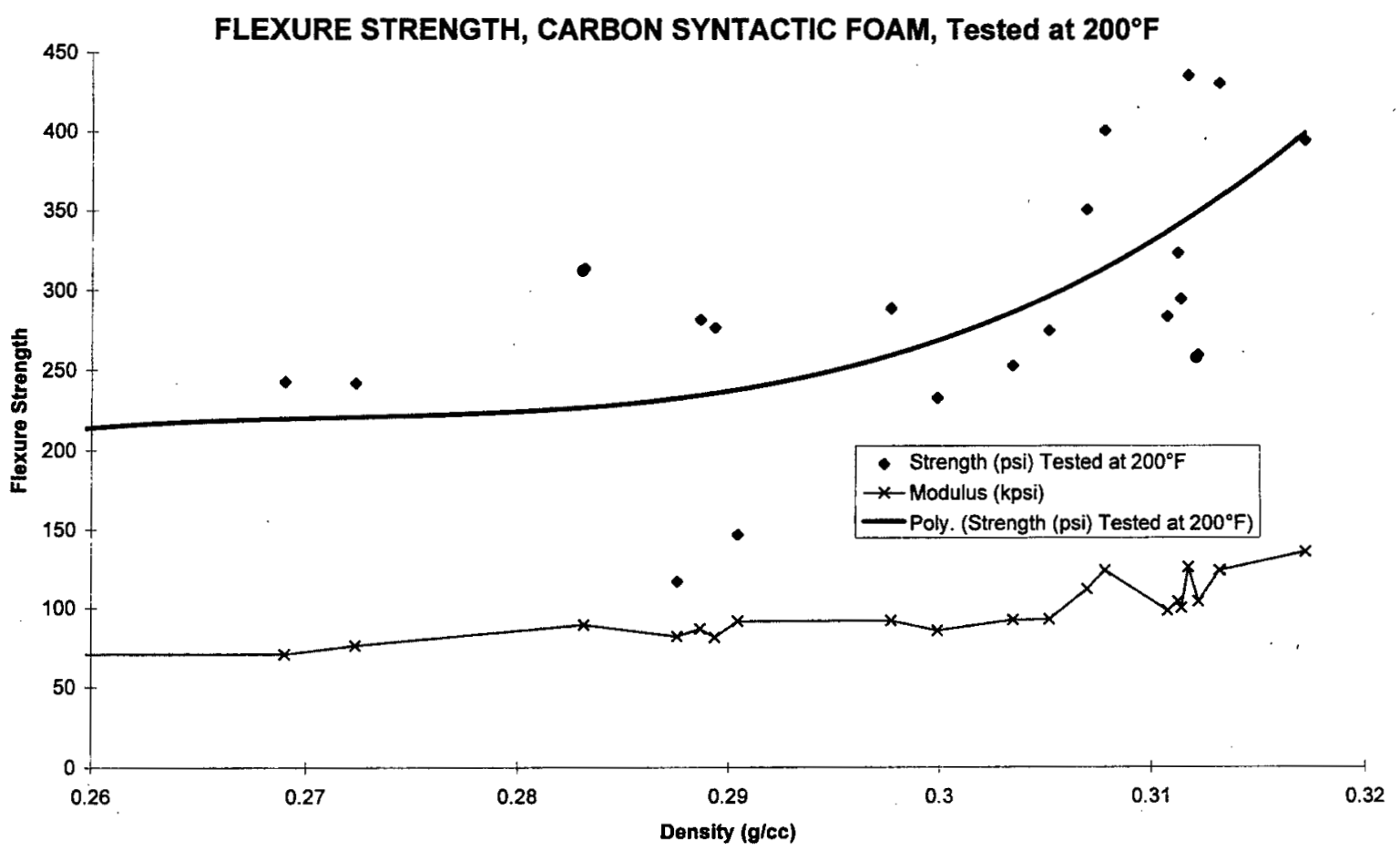

Figure 9. Flexure Strength and Modulus of Elasticity Versus Density, Tested at $200^{\circ} \mathrm{F}$ 


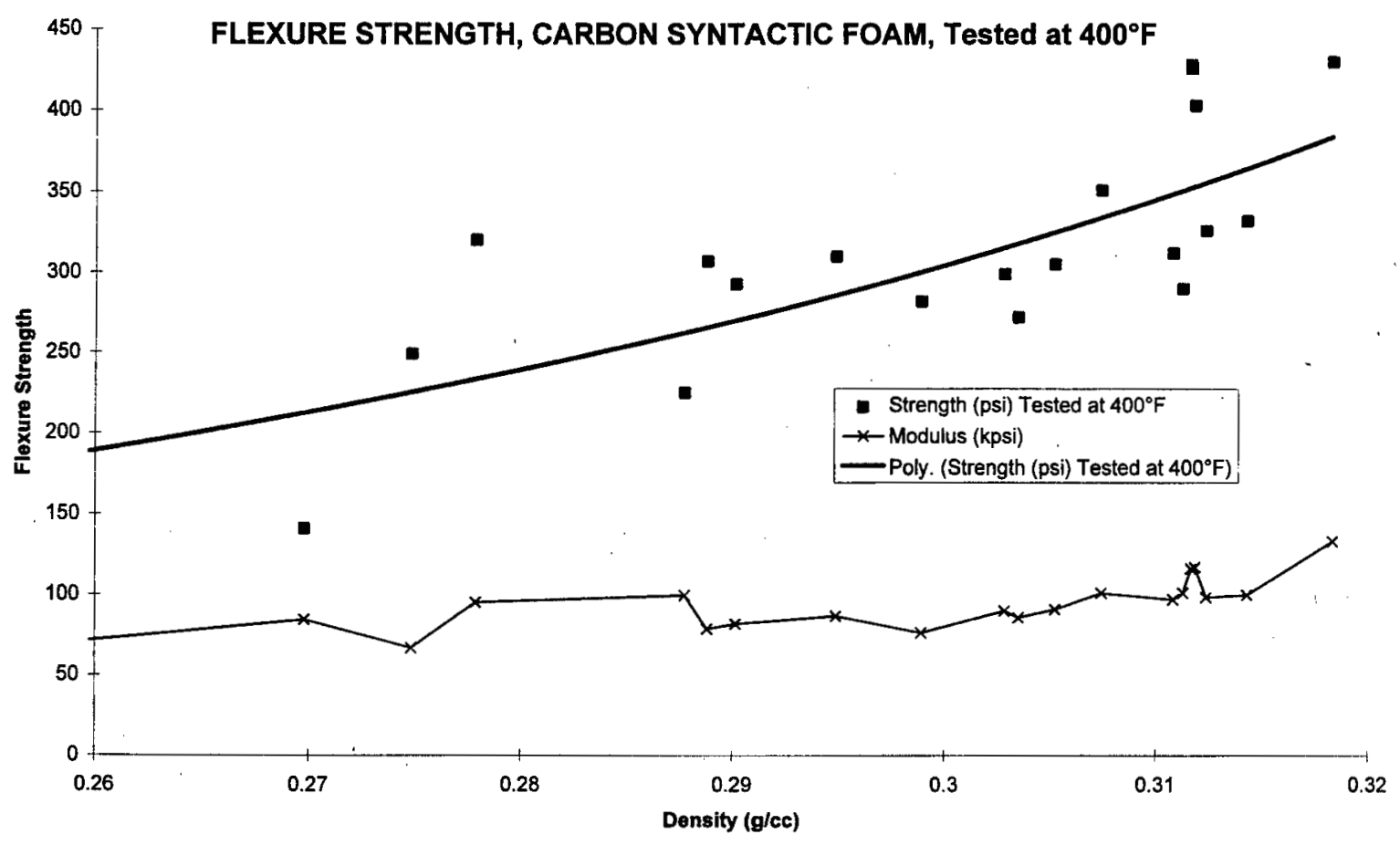

Figure 10. Flexure Strength and Modulus of Elasticity Versus Density, Tested at $400^{\circ} \mathrm{F}$

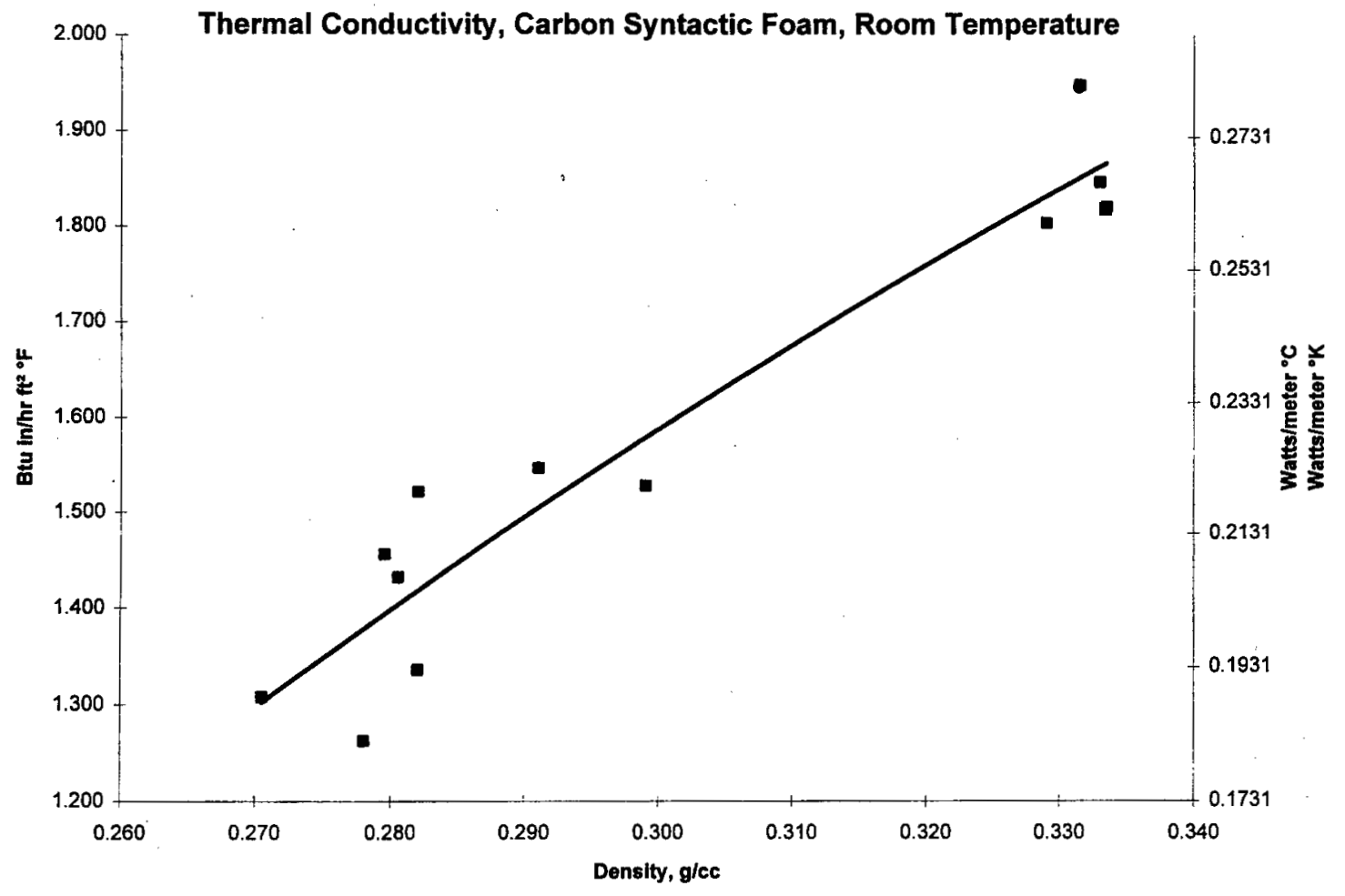

Figure 11. Thermal Conductivity of Carbon Syntactic Foam, Tested at Room Temperature 


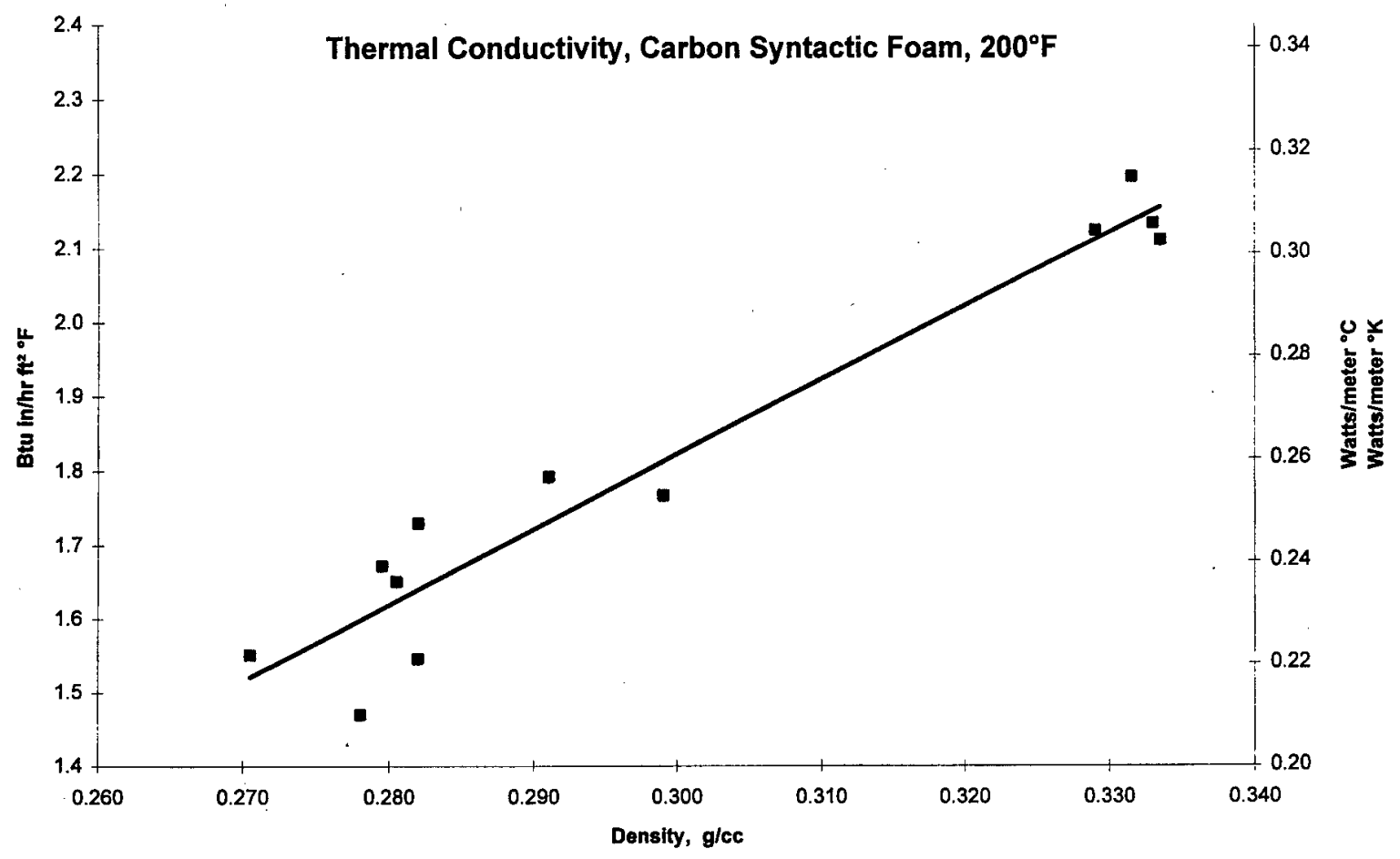

Figure 12. Thermal Conductivity of Carbon Syntactic Foam Versus Density, Tested at $200^{\circ} \mathrm{F}$

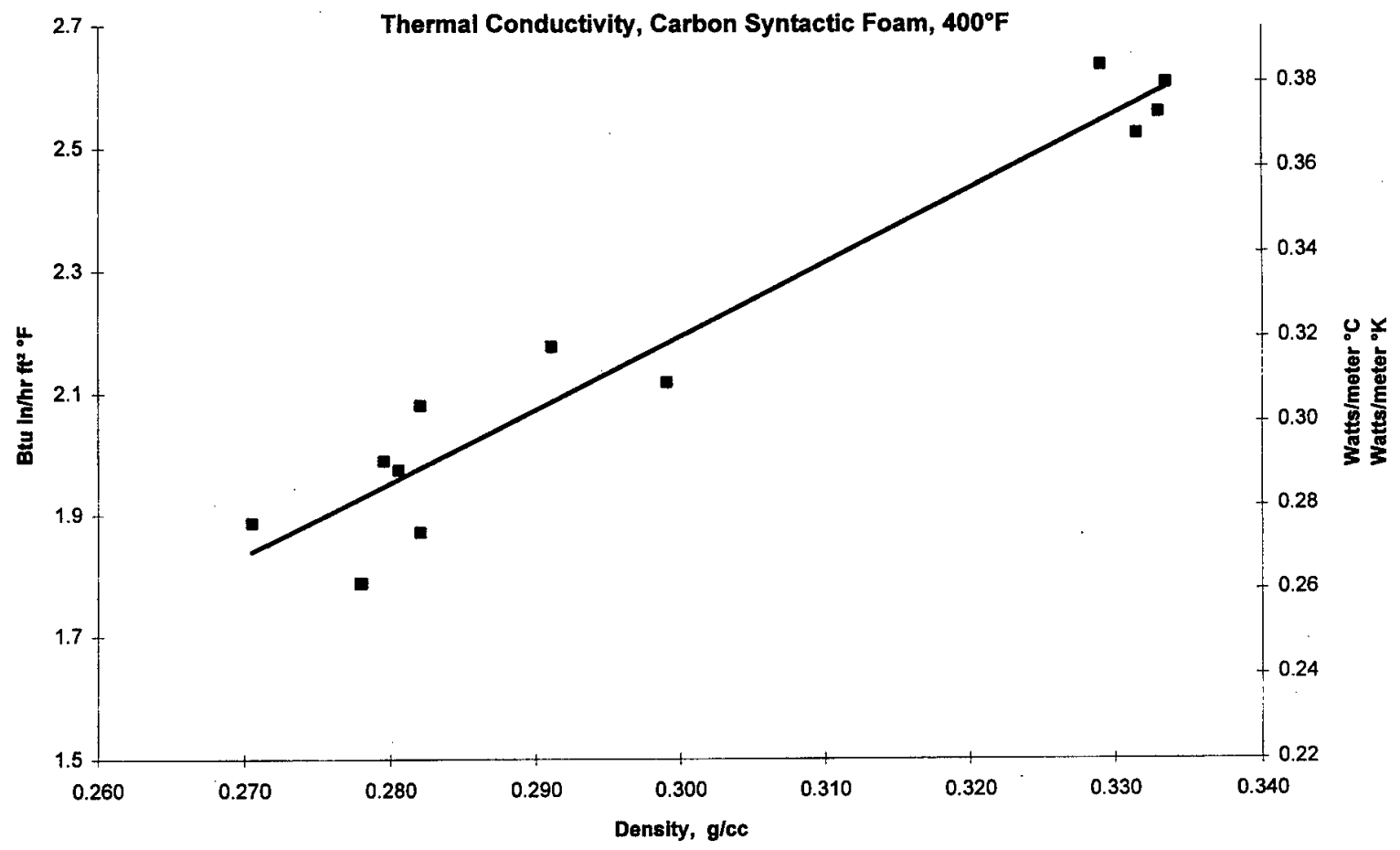

Figure 13. Thermal Conductivity of Carbon Syntactic Foam Versus Density, Tested at $400^{\circ} \mathrm{F}$ 


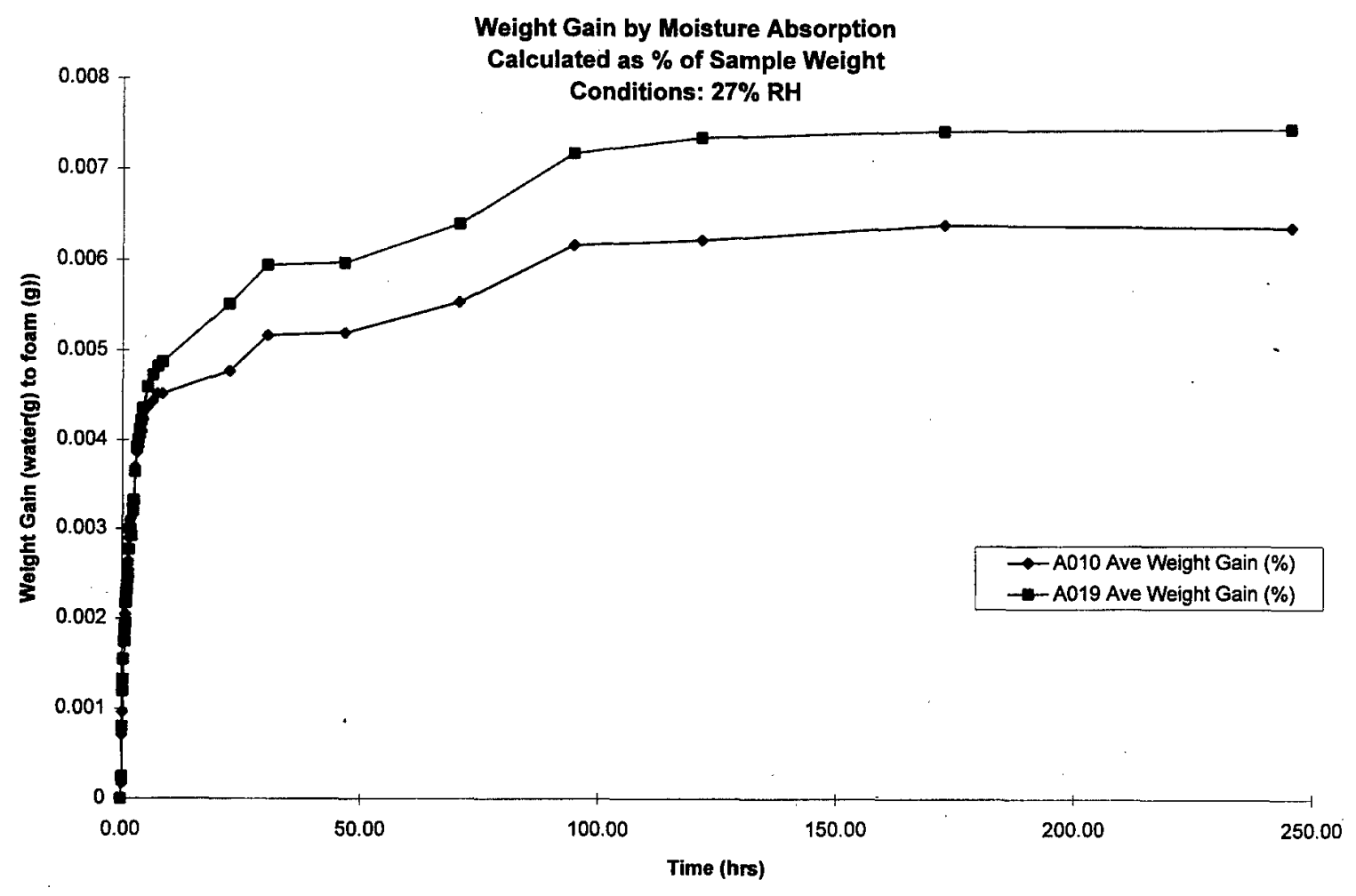

Figure 14. Moisture Absorption in Carbon Syntactic Foam 
M98051592

||||||||||||||||||||||||||||||||||||-1.4

Report Number (14) KCP--6/3-6043

Publ. Date (11) 199801

Sponsor Code (18) DOE/DP, XF

UC Category (19) $U C-706, D O E / E R$

DOE 